\title{
EPA-TG 乳剂静脈投与による家鬼への影響
}

\author{
浦風 雅春* 浜崎 智化* 矢野 三郎* 熊谷 朗**
}

\author{
The effects of EPA-TG \\ intravenons administration into rabbits \\ Masaharu URAKAZE*, Tomohito HAMAZAKI*, \\ Saburo YANO* and Akira KUMAGAI**
}

Key words: 1, 2, 3-trieicosapentaenoyl-glycerol, EPA-TG emulsion, platelet aggregation, serum lipids, liver function

Anti-platelet and anti-atherogenic properties of eicosapentaenoic acid (EPA) are being focused. We have reported that platelet aggregation is depressed after intravenous infusion of emulsion of fish oil containing $30 \%$ EPA. We, then, manufactured an emulsion of 1,2,3-trieicosapentaenoylglycerol (EPA-TG). 90\% of fatty acids in EPA-TG were EPA. We examined influences of two intravenous injections of the EPA-TG emulsion on platelet aggregation, serum lipids and liver function in rabbits. Platelet aggregation induced by $\mathrm{ADP}(5 \mu \mathrm{M})$ and collagen $(10 \mu \mathrm{g} / \mathrm{ml})$ was depressed significantly after injections. No significant changes in serum lipids and liver function were observed after injections. Our results suggest that in those patients, who can not eat anything, such as postoperative patients, EPA-TG emulsion may inhibit the initiation and progression of thrombosis.

は じめに エイコサペンタェン酸 (EPA) は, 魚油に多 く含まれている多価不飽和脂肪酸の一種で, 抗
血小板，抗動脈硬化作用をもつことが報告され ている1 3).われわれは, 先に, 約30\%の EPA を含む魚油を, 卵黄リン脂質で乳化し作製した 魚油乳剂を家鬼に点滴静注し，短期間に特ける

* 富山医科薬科大学医学部第一内科 [ $7930-01$ 富山市杉谷 2630], The First Department of Internal Medicine, Faculty of Medicine, Toyama Medical and Pharmaceutical University, Toyama, Japan

** 富山医科薬科大学, Toyama Medical and Pharmaceutical University, Toyama, Japan 
a)

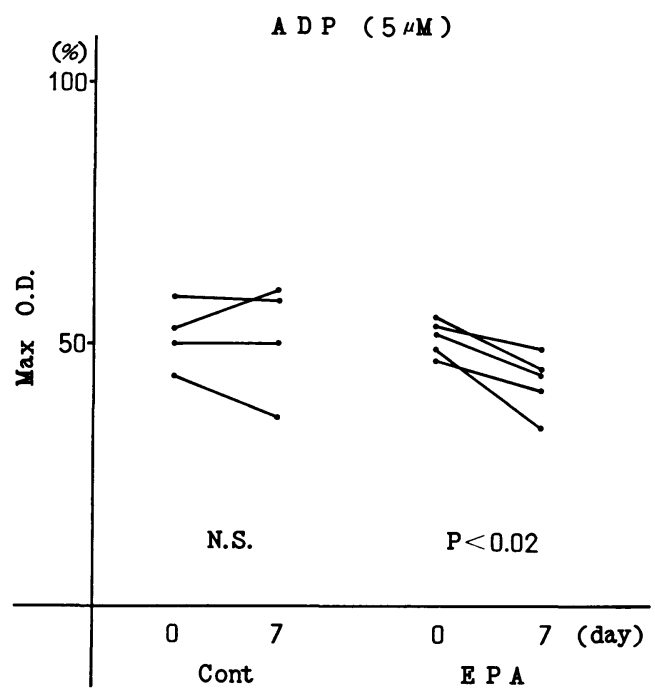

b)

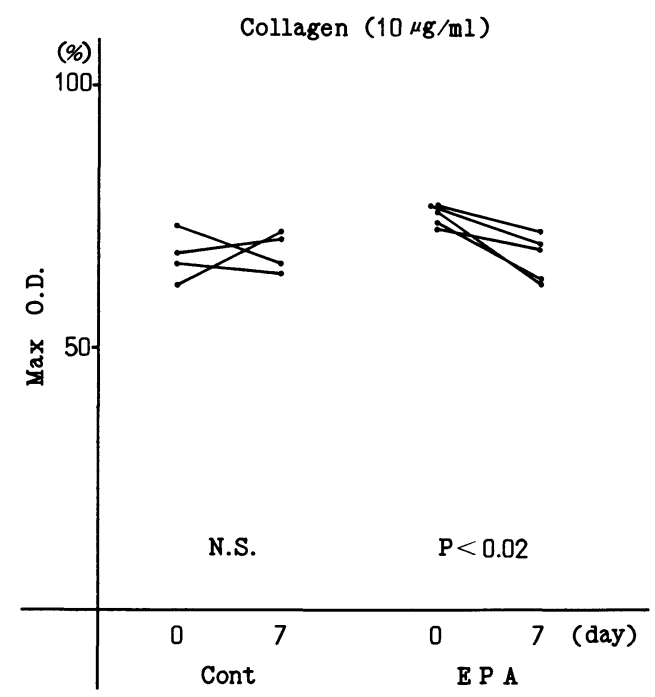

Fig. 1 Changes in platelet aggregation induced by a) ADP $(5 \mu \mathrm{M})$ and b) collagen $(10 \mu \mathrm{g} / \mathrm{m} l)$ after injections

EPA の血小板凝集能抑制効果を報告した4).今 回，われわれは，1，2，3-trieicosapentaenoylglycerol (EPA-TG) を用いて乳剤を作製し， 家鬼に静注し，血小板凝集能ならびに，血清脂 質，肝機能に及ぼす影響を検討したので報告す る.

\section{I. 方 法}

体重約 $3 \mathrm{~kg}$ の家鬼 9 羽を 2 群に分け, 一群 $(\mathrm{n}=5)$ には, EPA-TG 乳剤を, もら一群 (n =4）には，対照として大豆油乳剂を投与した.

1 日目と 4 日目に，それぞれの乳剤約 $33 \mathrm{ml}$ を ゆっくりと静注し，0日目と7日目に採血を行 った. 乳剤 $100 \mathrm{ml}$ 中には, TG $10 \mathrm{~g}$, グリセ リン $2.5 \mathrm{~g}$, リン脂質 $1.2 \mathrm{~g}$ が含まれている.

EPA-TG 乳剂中の脂肪酸の $90 \%$ EPA であ り, 約 $1 \mathrm{~g} / \mathrm{kg}$ の EPA が，一回の静注で投与 される. 血小板凝集能は, PRPを用い, 比濁 法により測定した。凝集惹起物質として，ADP コラーゲンを用いた。 また，血清脂質，肝機 能に及ぼす影響を調べるため，TG，T-Ch， PL, FFA, POXL (過酸化脂質), GOT, GP T, $\gamma$-GTP を, オートアナライザーで測定し た. 統計的処理は, paired t-testにて行った.

\section{II. 結 果}

体重, 血小板数は, 両群ともに, 有意な変化 はみられなかった、へマトクリット $(\mathrm{Ht})$ は両 群ともに低下していた.

\section{1. 血小板凝集能の变化 (図 1 )}

EPA-TG 群では，ADP，コラーゲンによる 血小板凝集能は，どちらも有意な低下を示した が，大豆油群では，有意な変化はみられなかっ た.

2. 血清脂質, 肝機能に及ぼす影響（表 1 ）

EPA-TG 群に颃いては，有意な変化を示し たパラメーターはみられなかったが，大豆油群 では, FFA が有意な増加を示し, GPT が増加 傾向 $(0.05<\mathrm{p}<0.1)$ を示した.

\section{III. 考察}

EPA の投与実験は，これまで数多くなされ ているが，経口投与によるものが汪とんどであ る ${ }^{5 \sim 7)}$. しかし, 臨床に执いては, 腹部手術の 術後や, 脳血管障害の急性期あるいは癌患者の 末期など，経口摂取不可能な状態にある患者も 多数存在する.そこで，われわれは，EPA-TG 乳剂を作製し, 静注実験を行った. 投与後, $\mathrm{ADP}$, コラーゲンによる血小板凝集能は，有意 
Table 1 Changs of paremeters after injections

\begin{tabular}{c|c|c||c|c}
\hline \multirow{2}{*}{} & \multicolumn{2}{|c||}{ Soybean Oil (n=4) } & \multicolumn{2}{c}{ EPA-TG (n=5) } \\
\cline { 2 - 3 } & Before & After & Before & After \\
\hline T-Ch & $40.5 \pm 6.3$ & $40.0 \pm 5.8$ & $28.0 \pm 2.1$ & $37.8 \pm 16.5$ \\
TG & $58.8 \pm 25.4$ & $79.8 \pm 27.0$ & $57.0 \pm 9.1$ & $73.0 \pm 14.3$ \\
PL & $73.3 \pm 11.1$ & $79.8 \pm 9.8$ & $53.2 \pm 5.6$ & $62.8 \pm 10.6$ \\
FFA & $0.32 \pm 0.1$ & $0.56 \pm 0.1^{* *}$ & $0.31 \pm 0.2$ & $0.41 \pm 0.1$ \\
POXL & $1.6 \pm 0.9$ & $1.5 \pm 0.3$ & $1.8 \pm 1.0$ & $1.6 \pm 0.1$ \\
GOT & $14.3 \pm 5.6$ & $17.5 \pm 3.4$ & $17.2 \pm 14.0$ & $42.2 \pm 47.1$ \\
GPT & $21.0 \pm 5.5$ & $26.8 \pm 8.9$ & $22.8 \pm 5.4$ & $27.0 \pm 9.4$ \\
rGTP & $7.3 \pm 1.6$ & $7.3 \pm 0.4$ & $8.0 \pm 1.9$ & $7.4 \pm 2.2$ \\
Ht & $41.6 \pm 2.0$ & $38.5 \pm 1.1 *$ & $41.4 \pm 2.1$ & $38.7 \pm 2.1 * *$ \\
Plateletr & $28.0 \pm 6.4$ & $24.8 \pm 8.2$ & $31.4 \pm 7.9$ & $31.7 \pm 6.9$ \\
\hline & $*$ p $<0.05$ & $* * \mathrm{p}<0.01$ &
\end{tabular}

な低下を示したが，血清脂質，肝機能に及汸す 悪影響はみられなかった．以上の結果は，血小 板凝集能の抑制と高カロリ一輸夜が，同時に必 要な場合に和ける，EPA-TG 乳剤の臨床応用 の可能性を示唆するものと思われる.

\section{文 献}

1) Dyerberg, J., Bang, H.O., Stoffersen, E., Moncada, S. and Vane, J.R.: Eicosapentaenoic acid and prevention of thrombosis and atherosclerosis? Lancet, 2; 117 119, 1978.

2) Goodnight, S.H. Jr., Harris, W.S., Conner, W.E. and Illingworth, D.R.: Polyunsaturated fatty acids, hyperlipemia, and thrombosis. Arteriosclerosis, 2; 87 113, 1982.

3) Siess, W., Roth, P., Scherer, B., Kurzmann, T., Böhlig, B. and Weber, P.C.: Platelet-membrane fatty acids, platelet aggregation, and thromboxane formation during a mackerel diet. Lancet, 1; 441 444, 1980.

4）浦風雅春, 浜崎智壬, 矢野三郎, 小林 悟 :
イコサペンタェン酸 $(E P A)$ 濃縮魚油乳剤の家 鬼一の点滴静注. 動脈硬化, 13；1421 1425, 1986 ,

5) Vas Dias, F.W., Gibney, M.J. and Taylor, T.G.: The effect of polyunsaturated fatty acids of the $n-3$ and $n-6$ series on platelet and aortic fatty acid composition in rabbits. Atherosclerosis, 43; 245 257, 1982.

6) Hamazaki, T., Hirai, A., Terano, T., Sajiki, J., Kondo, S., Fujita, T., Tamura, Y. and Kumagai, A.: Effects of orally administered ethyl ester of eicosapentaenoic acid (EPA; C20:5, $\omega-3)$ on $\mathrm{PG} \mathrm{I}_{2}$ like substance production by rat aorta. Prostaglandins, 23; 557 567, 1982.

7) Strasser, T., Fischer, S. and Weber, P.C.: Leukotriene $B_{5}$ is formed in human neutrophils after dietary supplementation with eicosapentaenoic acid. Proc. Natl. Acad. Sci., U.S.A., 82; 1540 1543, 1985. 